\title{
Mitigation mechanism of ozone-induced reduction in net photosynthesis of Bangladeshi wheat under soil salinity stress
}

\author{
M.Z.U. KAMAL ${ }^{*, * *}$, M. YAMAGUCHI ${ }^{* *, \#,}$, Y. KINOSE*,\#, and T. IZUTA ${ }^{\# \#,++}$ \\ United Graduate School of Agricultural Science, Tokyo University of Agriculture and Technology, Fuchu, \\ Tokyo 183-8509, Japan* \\ Faculty of Graduate Studies, Bangabandhu Sheikh Mujibur Rahman Agricultural University, Gazipur-1706, \\ Bangladesh $^{* *}$ \\ Graduate School of Agriculture, Tokyo University of Agriculture and Technology, Fuchu, Tokyo 183-8509, Japan*** \\ Graduate School of Fisheries and Environmental Sciences, Nagasaki University, Nagasaki, Nagasaki 852-8521, \\ Japan $^{\#}$ \\ Graduate Faculty of Interdisciplinary Research, University of Yamanashi, Kofu, Yamanashi 400-8510, Japan \\ Institute of Agriculture, Tokyo University of Agriculture and Technology, Fuchu, Tokyo 183-8509, Japan \#\#
}

\begin{abstract}
To clarify the combined effects of $\mathrm{O}_{3}$ and soil salinity on net photosynthetic rate, stomatal conductance, and radical scavenging system of Bangladeshi spring wheat cv. BAW1059, plants were grown in two soil salinity levels (irrigated with 0 and $150 \mathrm{mM} \mathrm{NaCl}$ solutions) and exposed to three $\mathrm{O}_{3}$ concentrations [charcoal-filtered air (CF), 1.0-fold the ambient $\mathrm{O}_{3}$ concentration $\left(1.0 \times \mathrm{O}_{3}\right)$, and 1.5-fold the ambient $\mathrm{O}_{3}$ concentration $\left.\left(1.5 \times \mathrm{O}_{3}\right)\right]$. The soil salinity mitigated adverse effects of $\mathrm{O}_{3}$ on net photosynthesis in the $7^{\text {th }}$ and flag leaves. The soil salinity did not induce stomatal closure, indicating no limitation of stomatal $\mathrm{O}_{3}$ uptake. The activities of ascorbate peroxidase and catalase were stimulated by the soil salinity in the $7^{\text {th }}$ and flag leaves, especially under $1.5 \times \mathrm{O}_{3}$ concentration. In the flag leaf, the soil salinity induced a significant increase in dehydroascorbate reductase activity and ascorbate concentration. These results suggest that the soil salinity activated detoxification capacity related to mitigation of $\mathrm{O}_{3}$ damage on net photosynthesis in both $7^{\text {th }}$ and flag leaves, while the activated enzymes and antioxidants were different between the leaves.
\end{abstract}

Additional key words: antioxidant; detoxification; leaf position; radical scavenging system; stomatal conductance.

\section{Introduction}

Elevated concentrations of ground-level ozone $\left(\mathrm{O}_{3}\right)$ result from photochemical reactions of the $\mathrm{O}_{3}$ precursors, i.e., nitrogen oxides $\left(\mathrm{NO}_{\mathrm{x}}\right)$ and volatile organic compounds (VOC) (WHO 2006), and may pose a great threat to global food security and economy (Avnery et al. 2013). The current global surface $\mathrm{O}_{3}$ concentration has more than doubled since the industrial revolution (WHO 2006). There is a probability that over the next 20-30 years, atmospheric concentrations of $\mathrm{O}_{3}$ will increase especially in South Asia (Wild et al. 2012). Therefore, we need to evaluate the effects of $\mathrm{O}_{3}$ on crops cultivated in South Asian countries such as Bangladesh, and implement countermeasure against the detrimental effects of $\mathrm{O}_{3}$ on main crops such as rice and wheat.

Ozone absorbed into the leaves of crops through stomata produces reactive oxygen species (ROS), such as hydrogen peroxide $\left(\mathrm{H}_{2} \mathrm{O}_{2}\right)$, superoxide $\left(\mathrm{O}_{2}{ }^{-}\right)$, singlet oxygen $\left({ }^{1} \mathrm{O}_{2}\right)$, and hydroxyl radicals ( $\left.{ }^{\circ} \mathrm{OH}\right)$ (Pell et al. 1997, Ainsworth et al. 2012). Although a part of ROS generated by $\mathrm{O}_{3}$ can be detoxified in the leaves by radical-scavenging system, the remaining ROS cause oxidative stress in the leaf cells (Gill and Tuteja 2010). As a result, $\mathrm{O}_{3}$ leads to reductions in net photosynthetic rate and other biochemical processes in the leaves, and finally in the growth and yield of crops (Akhtar et al. 2010, Gerosa et al. 2014). There are controversial empirical data on $\mathrm{O}_{3}$-induced alteration of detoxification

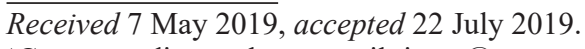

${ }^{+}$Corresponding author; e-mail: izuta@cc.tuat.ac.jp

Abbreviations: $1.0 \times \mathrm{O}_{3}-1.0$-fold the ambient $\mathrm{O}_{3}$ concentration; $1.5 \times \mathrm{O}_{3}-1.5$-fold the ambient $\mathrm{O}_{3}$ concentration; $\mathrm{AOT} 40$ - accumulated $\mathrm{O}_{3}$ exposure over a threshold of $40 \mathrm{ppb}$; APX - ascorbate peroxidase; AsA - reduced ascorbate; CAT - catalase; CF - charcoal-filtered air; DHA - oxidized ascorbate; DHAR - dehydroascorbate reductase; FM - fresh mass; GR - glutathione reductase; $g_{\mathrm{s}}$ - stomatal conductance to $\mathrm{H}_{2} \mathrm{O}$; GSH - reduced glutathione; GSSG - oxidized glutathione; MDAR - monodehydroascorbate reductase; $\mathrm{NO}_{\mathrm{x}}$ - nitrogen oxides; $P_{\mathrm{N}}$ - net photosynthetic rate; $\mathrm{PVPP}$ - polyvinyl polypyrrolidone; ROS - reactive oxygen species; $\mathrm{SOD}$ - superoxide dismutase; VOC - volatile organic compounds.

Acknowledgements: The first author was supported by the MEXT Scholarship Program (Ministry of Education, Culture, Sports, Science, and Technology in Japan). The first author also thanks Mr. Hirofumi Shimada, Dr. Rashied Tetteh, Mr. Yu Taniguchi, and Dr. Nahid Akhtar for their support during the experimental period. 
capacity in plants. The $\mathrm{O}_{3}$-induced $\mathrm{ROS}$ scavenging mechanisms are mostly a matter of the concentrations or dose, frequency of the ozone exposure in relation to the genetic base of plants (Bellini and Tullio 2019). Gillespie et al. (2012) suggested that total antioxidant capacity of soybean plant was increased with chronic exposure to elevated $\mathrm{O}_{3}$. Bortolin et al. (2014) found that elevated $\mathrm{O}_{3}$ significantly decreased antioxidant defense capacity in red pepper plant. Moreover, in a FACE study, elevated $\mathrm{O}_{3}$ consistently showed a declining trend of antioxidant pools and key enzymes of two different $\mathrm{O}_{3}$-sensitive wheat cultivars (Wang et al. 2014). Although there is a lot of information on the effects of $\mathrm{O}_{3}$ on physiological functions and detoxification capacity against ROS of crops cultivated in the USA and Europe, very limited information is available for crops cultivated in South Asian countries, such as Nepal, Pakistan, Bangladesh, Afghanistan, and Sri Lanka to date (Akhtar et al. 2010, Saitanis et al. 2014).

In Bangladesh, in addition to atmospheric $\mathrm{O}_{3}$, soil salinity is recognized as a serious problem for production of crops such as wheat, which is one of the major grain crops in this country. Over $30 \%$ of cropland in Bangladesh is under various levels of soil salinity (Haque 2006). In general, soil salinity stress induces stomatal closure (Sharma et al. 2012), which can mitigate detrimental effects of $\mathrm{O}_{3}$ on crops due to the limitation of stomatal $\mathrm{O}_{3}$ uptake. On the other hand, the adverse effects of $\mathrm{O}_{3}$ on crops might be enhanced by soil salinity-induced reduction in leaf antioxidant capacity (Zheng et al. 2012). Several studies reveal that increased salinity level enhances the activities of both enzymatic and nonenzymatic antioxidants in plants (Ghosh et al. 2011, Hasanuzzaman et al. 2011). Moreover, Zheng et al. (2011) found that the combined effects of $\mathrm{O}_{3}$ and salinity increased antioxidant enzyme activity significantly only in the salt-sensitive wheat cultivar and projected a complementary defense for both stresses. Still, there is uncertainty about the antioxidant defense mechanisms under $\mathrm{O}_{3}$ and salinity stress. Furthermore, information on the combined effects of $\mathrm{O}_{3}$ and soil salinity on Bangladesh wheat cultivar and its defense mechanism are extremely limited to date.

In our previous study, we clarified the exposure to $\mathrm{O}_{3}$ singly decreased net photosynthetic rate of flag leaves of BAW1059, which is the cultivar with relatively high yield under salinity stress (Kamal et al. 2015). On the other hand, there was no significant interactive effect of $\mathrm{O}_{3}$ and soil salinity on net photosynthetic rate of the leaves at anthesis stage (Kamal et al. 2015). Several investigations also reported inconsistent effects of $\mathrm{O}_{3}$ and/or salinity on different biochemical attributes and defense mechanisms at different growth stages (Ashraf et al. 2012, Rai and Agrawal 2014). Interactive effects of $\mathrm{O}_{3}$ and soil salinity may be observed in the other growth stages, e.g., at the vegetative stage. Therefore, further research is needed to clarify the combined effects of $\mathrm{O}_{3}$ and soil salinity on net photosynthesis of Bangladeshi wheat at different growth stages and across leaf positions.

In the present study, we hypothesized that soil salinity can affect the sensitivity of wheat to $\mathrm{O}_{3}$ through its effects on stomatal $\mathrm{O}_{3}$ uptake and/or leaf antioxidant capacity depending on the growth stages and leaf positions. In order to clarify this, we investigated net photosynthetic rate, stomatal conductance, and radical scavenging system of Bangladeshi wheat cultivar, BAW1059, under elevated $\mathrm{O}_{3}$ and soil salinity stresses.

\section{Materials and methods}

Plant materials: In the present study, we used Bangladeshi spring wheat (Triticum aestivum L.) cultivar, BAW1059, which is one of the widely grown spring wheat cultivars in Bangladesh. Seeds of this wheat cultivar were obtained from Bangladesh Agricultural Research Institute (BARI). The cultivar has potential yields of 3.6-5.0 $\mathrm{t} \mathrm{ha}^{-1}$ in Bangladesh (Barma et al. 2011). We adopted standard cultivation methods, such as preparation of the soil and fertilization, performed commonly in wheat fields in Bangladesh. On 31 March 2014, the seeds were sown in Wagner pots (volume: $12 \mathrm{~L}$, diameter: $240 \mathrm{~mm}$, and depth: $258.5 \mathrm{~mm}$ ) filled with horticultural soil at three hills and three seeds per hill. The seedlings were thinned to leave one seedling per hill on 15 May. Accordingly, the final number of plants per pot was three. The textural class of the studied soil was sandy loam, having an initial soil $\mathrm{pH}$ 5.73. The potted soil contained similar amounts of $\mathrm{N}$, $\mathrm{P}$, and $\mathrm{K}\left(384 \mathrm{mg} \mathrm{L}^{-1}\right)$. Before sowing the seeds, $5 \mathrm{~g}$ of $\mathrm{CaCO}_{3}$ mixed thoroughly in each pot to a depth of $15 \mathrm{~cm}$, was added for correction of soil acidity. Before the gas exposure and soil salinity treatment, the seedlings were raised in open-air condition for $26 \mathrm{~d}$ from 31 March to 25 April 2014. During this period, average 12-h $\mathrm{O}_{3}$ concentration (06:00-18:00 h) was 47.1 nL L ${ }^{-1}$ (ppb), and air temperature and relative air humidity fluctuated between $0-22.8^{\circ} \mathrm{C}$ and $13.8-97.6 \%$, respectively.

Gas-exposure chambers: The experiment was conducted at the Field Museum Tamakyuryo of Tokyo University of Agriculture and Technology $\left(35^{\circ} 38^{\prime} \mathrm{N}, 139^{\circ} 22^{\prime} \mathrm{E}\right)$ situated in Hachioji, Tokyo, Japan, from March to July 2014. Nine commercial-type vinyl greenhouses were used as gasexposure chambers in the present study. The fumigation chambers (length: $3.6 \mathrm{~m}$, width: $2.2 \mathrm{~m}$, height: $2.0 \mathrm{~m}$ ) were built with steel pipe construction covered with soft transparent polyvinyl chloride film (average light transmittance of 73\%). PPFD under the ambient conditions (outside the chambers) was recorded at 1-min intervals using a quantum sensor (LI-190SA, Li-Cor Inc., Lincoln, NE, USA). In three of the nine chambers, temperature and humidity sensors (TR-72U, T\&D Corporation, Nagano, Japan) were set to monitor the air temperature and relative air humidity inside the chambers at 10-min interval.

The air passed through an activated charcoal filter in the fan box (EF-40DTB1, Mitsubishi Electric Co., Tokyo, Japan) in order to remove $\mathrm{O}_{3}$ from the ambient air, and introduced in each chamber at a flow rate of $1.03 \mathrm{~m}^{3} \mathrm{~s}^{-1}$. Ozone was produced by a silent electrical discharge $\mathrm{O}_{3}$ generator (OZC-05A, Dylec Inc.) from oxygen-enriched dry air generated from the ambient air by a pressureswing adsorption-type oxygen enricher (SO-008S, Sanyo Electronic Inc., Okayama, Japan). The $\mathrm{O}_{3}$ was delivered 
to the chamber after quick mixing with charcoal-filtered air through a high-speed fan. The $\mathrm{O}_{3}$ concentrations in each chamber and in the ambient air were recorded at 30and 10-min intervals, respectively, using UV absorption $\mathrm{O}_{3}$ analyzer (Model-1210, Dylec Inc., Ibaraki, Japan) throughout the experimental period. For the control of atmospheric $\mathrm{O}_{3}$ concentration in the $\mathrm{O}_{3}$-exposure chambers, the ambient $\mathrm{O}_{3}$ concentration was used as the standard level. Based on the $\mathrm{O}_{3}$ concentration in the chambers, mean concentration and accumulated $\mathrm{O}_{3}$ exposure over a threshold of $40 \mathrm{ppb}$ (AOT40) were calculated.

Experimental design and treatment exposure: The experiment was designed as a split-split plot with three gas-exposure chamber replications. The whole-plot treatment comprised of three different $\mathrm{O}_{3}$ concentrations using nine gas-exposure chambers: charcoal-filtered air (CF) (mean $\mathrm{O}_{3}$ removal efficiency: 54\%), 1.0-fold the ambient $\mathrm{O}_{3}$ concentration $\left(1.0 \times \mathrm{O}_{3}\right)$, and 1.5 -fold the ambient $\mathrm{O}_{3}$ concentration $\left(1.5 \times \mathrm{O}_{3}\right)$. Two levels of saline irrigation (0 or $150 \mathrm{mM} \mathrm{NaCl}$ solution) embraced as sub-plot treatment. Wheat seedlings established in an open space were transferred to the nine gas-exposure chambers on 26 April 2014 for introducing gas-exposure and soil salinity treatment until 12 June 2014. In each gas-exposure chamber, four pots (i.e., 12 seedlings) were assigned to each soil salinity treatment. One liter of 0 or $150 \mathrm{mM} \mathrm{NaCl}$ solution was applied to each pot at 4-d intervals during the exposure period. There is strong evidence that irrigation water with an $\mathrm{EC} \geq 13 \mathrm{dS} \mathrm{m}^{-1}$ or $130 \mathrm{mM} \mathrm{NaCl}$ solution significantly suppressed the growth and yield of Bangladeshi wheat under field conditions (Mojid et al. 2013, Bilkis et al. 2016). During the growing period, a total of 15 saline irrigations (4-d interval) were done using $150 \mathrm{mM} \mathrm{NaCl}$ solution. The 4 -d interval was selected to prevent the washout of salt from the soil. To avoid soil drying and prevent salt accumulation, deionized water was applied as necessary. The soil EC was 0.5 and $6.1 \mathrm{dS} \mathrm{m}^{-1}$ in $0 \mathrm{mM}$ and $150 \mathrm{mM} \mathrm{NaCl}$ treatments, respectively.

Leaf gas-exchange rates: Net photosynthetic rate $\left(P_{\mathrm{N}}\right)$ and stomatal conductance to $\mathrm{H}_{2} \mathrm{O}\left(g_{\mathrm{s}}\right)$ were measured ex situ in the chamber using a portable photosynthetic measurement system (LI-6400, Li-Cor Inc., Lincoln, NE, USA). The measurements of gas-exchange rates were made for the fully expanded $7^{\text {th }}$ leaf from the plant bottom at the vegetative stage on 10-13 May 2014 and flag leaves at the anthesis stage on 7-11 June 2014 of three randomly selected plants per treatment $\times$ chamber combination (nine measurements per treatment and one plant per pot). The $P_{\mathrm{N}}$ and $g_{\mathrm{s}}$ were measured at stable environmental conditions: atmospheric $\mathrm{CO}_{2}$ concentration of $390 \mu \mathrm{mol} \mathrm{mol}{ }^{-1}$, air temperature of $25 \pm 1^{\circ} \mathrm{C}$, relative air humidity of $70 \pm 5 \%$, indicating $\mathrm{VPD} \approx 1.0 \mathrm{kPa}$, and PPFD of $1,500 \mu \mathrm{mol} \mathrm{m} \mathrm{m}^{-2} \mathrm{~s}^{-1}$.

Radical-scavenging enzyme assays: After a few days from the measurement period of gas-exchange rates, the $7^{\text {th }}$ and flag leaves from three randomly selected plants per treatment $\times$ chamber combination were collected on 15 May and 12 June 2014, respectively (nine plants per treatment). Immediately after the measurements of leaf area and fresh mass (FM), the leaves were frozen in liquid nitrogen and then stored at $-80^{\circ} \mathrm{C}$ until the measurements of radical-scavenging enzymes.

For the determination of activity of superoxide dismutase (SOD, EC 1.15.1.1), catalase (CAT, EC 1.11.1.6), monodehydroascorbate reductase (MDAR, EC 1.6.5.4), dehydroascorbate reductase (DHAR, EC 1.8.5.1), and glutathione reductase (GR, 1.8.1.7), the stored leaf samples (FM of $100 \mathrm{mg}$ ) were homogenized to fine powder with a mortar and pestle in liquid nitrogen with a small amount of quartz sand and polyvinyl polypyrrolidone (PVPP). Subsequently, $1 \mathrm{ml}$ of extraction buffer containing $50 \mathrm{mM}$ potassium phosphate $(\mathrm{pH} 7.8)$ and $1 \mathrm{mM}$ Na-EDTA was added to the leaf samples. The crude homogenate was centrifuged at $16,000 \times g$ for $10 \mathrm{~min}$ at $4^{\circ} \mathrm{C}$. The supernatant of the sample was used for the assay of the activities of MDAR, DHAR, and GR. The activity of MDAR was determined by the method described by Hossain and Asada (1984a). The supernatant $(80 \mu \mathrm{l})$ was added to $500 \mu \mathrm{l}$ of $100 \mathrm{mM}$ Tris-HCl buffer (pH 7.5), $100 \mu \mathrm{l}$ of $25 \mathrm{mM}$ L-ascorbic acid solution, $25 \mu \mathrm{l}$ of $4 \mathrm{mM}$ NADPH, and $294 \mu \mathrm{l}$ of deionized water in a disposable cuvette for blank measurement. The reaction of NADPH consumption by MDAR was activated by adding $1 \mu \mathrm{l}$ of ascorbate oxidase and monitored by absorbance at $340 \mathrm{~nm}$ using spectrophotometer (UVmini-1240, Shimadzu, Japan). The MDAR activity was calculated from consumption rate of NADPH using molar extinction coefficient of $6.30 \mathrm{mM}^{-1} \mathrm{~cm}^{-1}$, and expressed as $\mu \mathrm{kat}$ of NADPH $\mathrm{m}^{-2}$ (leaf area). For the measurement of DHAR activity, $20 \mu \mathrm{l}$ of supernatant was added to $500 \mu \mathrm{l}$ of $100 \mathrm{mM}$ potassium phosphate buffer ( $\mathrm{pH} 6.5), 330 \mu \mathrm{l}$ of deionized water, and $100 \mu \mathrm{l}$ of $25 \mathrm{mM}$ reduced glutathione (GSH). To activate the reaction of reduction of dehydroascorbic acid (DHA) by DHAR, $50 \mu \mathrm{l}$ of $10 \mathrm{mM}$ DHA was added, and the absorbance at $265 \mathrm{~nm}$ was measured for 2 min using the above spectrophotometer. The activity of DHAR was calculated from reduction rate of DHA using molar extinction coefficient of $14.3 \mathrm{mM}^{-1} \mathrm{~cm}^{-1}$ (Hossain and Asada 1984b), and expressed as $\mu$ kat of DHA $\mathrm{m}^{-2}$ (leaf area).

The activity of GR was determined by the method of Foyer and Halliwell (1976). For the measurement of GR activity, $200 \mu \mathrm{l}$ of the supernatant was added to $700 \mu \mathrm{l}$ of assay buffer containing $100 \mathrm{mM} \mathrm{KH}_{2} \mathrm{PO}_{4}(\mathrm{pH} 7.8)$ and $0.2 \mathrm{mM} \mathrm{Na-EDTA}(\mathrm{pH} 7.8)$, and $50 \mu \mathrm{l}$ of $2 \mathrm{mM}$ NADPH in a disposable cuvette for blank measurement. Subsequently, to activate the reaction of reduction of oxidized glutathione (GSSG) by GR, $10 \mathrm{mM}$ GSSG was added, and the absorbance at $340 \mathrm{~nm}$ was recorded for 2 min with the above spectrophotometer. The activity of GR was calculated from the consumption rate of NADPH using molar extinction coefficient of $6.10 \mathrm{mM}^{-1} \mathrm{~cm}^{-1}$, and expressed as $\mu$ kat of NADPH m ${ }^{-2}$ (leaf area).

For the measurement of activities of SOD and CAT, $500 \mu \mathrm{l}$ of the supernatant was desalted by applying it to $P D-10$ desalting column filled with Sephadex $G-25$. The activity of SOD was assessed according to McCord and Fridovich (1969). The reaction mixture contained 
$650 \mu \mathrm{l}$ of $50 \mathrm{mM}$ potassium phosphate buffer $(\mathrm{pH} 7.8)$ containing $0.1 \mathrm{mM}$ Na-EDTA, $100 \mu \mathrm{l}$ of $1 \mathrm{mM}$ xanthene solution, and $10 \mu \mathrm{l}$ of $1 \mathrm{mM}$ cytochrome $c$, and $220 \mu \mathrm{l}$ of desalted supernatant or extraction buffer. After blank quantify, the reaction was activated by adding $20 \mu \mathrm{l}$ of xanthene oxidase solution and absorbance was recorded at $550 \mathrm{~nm}$ for $2 \mathrm{~min}$ with the above spectrophotometer. Single unit of SOD activity (i.e., $\mu \mathrm{mol} \mathrm{min}^{-1}$ ) was defined as the amount of the enzyme required for inhibiting cytochrome $c$ reduction by $50 \%$. The activity of CAT was determined by $\mathrm{H}_{2} \mathrm{O}_{2}$ elimination rate monitored by absorbance at $240 \mathrm{~nm}$ with a molar extinction coefficient of $\mathrm{H}_{2} \mathrm{O}_{2}$ at $240 \mathrm{~nm}$ being $0.04 \mathrm{mM}^{-1} \mathrm{~cm}^{-1}$ (Aebi 1983). For CAT assay, an aliquot of $20 \mu \mathrm{l}$ of desalted supernatant was added

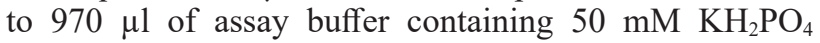
$(\mathrm{pH} 7.8)$ and $1 \mathrm{mM}$ EDTA in a quartz cuvette for blank measurement. The reaction was started by adding $10 \mu \mathrm{l}$ of $880 \mathrm{mM} \mathrm{H}_{2} \mathrm{O}_{2}$. The CAT activity was expressed as $\mu$ kat of $\mathrm{H}_{2} \mathrm{O}_{2} \mathrm{~m}^{-2}$ (leaf area).

To extract ascorbate peroxidase (APX), the stored leaf samples (FM of $100 \mathrm{mg}$ ) were homogenized to fine powder with a mortar and pestle in liquid nitrogen with a small amount of quartz sand and PVPP. Subsequently, $1 \mathrm{ml}$ of extraction buffer containing $50 \mathrm{mM}$ potassium phosphate ( $\mathrm{pH} 7.8$ ), $1 \mathrm{mM}$ Na-EDTA, and $5 \mathrm{mM}$ reduced ascorbic acid was added to the leaf samples. The crude homogenate was centrifuged at $16,000 \times g$ for $10 \mathrm{~min}$ at $4^{\circ} \mathrm{C}$. The supernatant of the sample was used for the assay of the APX activity. The activity of APX was assessed by measurement of reduced ascorbic acid oxidation via monitoring the decrease in absorbance at $290 \mathrm{~nm}$ and calculated using extinction coefficient of $2.8 \mathrm{mM}^{-1} \mathrm{~cm}^{-1}$ (Nakano and Asada 1981). The reaction mixture contained $10 \mu \mathrm{l}$ of crude supernatant, $920 \mu \mathrm{l}$ of $50 \mathrm{mM}$ potassium phosphate buffer ( $\mathrm{pH} 7.0$ ), and $50 \mu \mathrm{l}$ of $5 \mathrm{mM}$ L-ascorbic acid solution. Activation of reaction was started by adding $20 \mu \mathrm{l}$ of $50 \mathrm{mM} \mathrm{H} \mathrm{H}_{2}$ and subsequently recorded the decrease in absorbance at $290 \mathrm{~nm}$ for 2 min with the spectrophotometer. The activity of APX was expressed as $\mu$ kat of ascorbate $\mathrm{m}^{-2}$ (leaf area).

Concentration and redox state of antioxidants: At the same time of leaf sampling for the measurement of radical scavenging enzyme activity, the $7^{\text {th }}$ and flag leaves (FM of $30 \mathrm{mg}$ ) were collected from three randomly selected plants per treatment $\times$ chamber combination. Immediately after the measurements of leaf area and FM, the leaves were frozen in liquid nitrogen and then stored at $-80^{\circ} \mathrm{C}$ until the measurements of radical scavenging compounds.

The stored leaf samples were homogenized to fine powder in liquid nitrogen and subsequently $1.5 \mathrm{ml}$ of $5 \%(\mathrm{w} / \mathrm{v})$ metaphosphoric acid was added. The crude homogenate was centrifuged at $15,000 \times g$ for $10 \mathrm{~min}$ at $4^{\circ} \mathrm{C}$. The supernatant of the sample was used in the assay of the concentrations of ascorbate and glutathione.

The ascorbate concentration was determined by the modified method of Luwe and Heber (1995). For quantification of reduced ascorbate (AsA), $50 \mu$ l of the supernatant was added to $949 \mu \mathrm{l}$ of $100 \mathrm{mM}$ potassium phosphate buffer $(\mathrm{pH}$ 7.0). The reaction was activated by adding ascorbate oxidase ( 1 unit $\mu 1^{-1}$, Sigma-Aldrich), and the absorbance at $265 \mathrm{~nm}$ was monitored for $2 \mathrm{~min}$. The oxidized ascorbate (DHA) assay was done in a quartz cuvette containing $100 \mu \mathrm{l}$ of the supernatant, $899 \mu \mathrm{l}$ of $100 \mathrm{mM}$ potassium phosphate buffer $(\mathrm{pH} \mathrm{7.7)}$, and $1 \mu \mathrm{l}$ of $200 \mathrm{mM}$ dithiothreitol (DTT). The absorbance was monitored at $265 \mathrm{~nm}$ for $10 \mathrm{~min}$. The ascorbate concentration was calculated using the molar extinction coefficient of $14.3 \mathrm{mM}^{-1} \mathrm{~cm}^{-1}$. The redox state of ascorbate was expressed as the concentration ratio of AsA to total ascorbate (sum of AsA and DHA).

The concentration of glutathione was determined by the method of Griffith (1980). For the measurement of total glutathione (sum of reduced and oxidized glutathione), $195 \mu \mathrm{l}$ of neutralized supernatant was added to $660 \mu \mathrm{l}$ of assay buffer containing $125 \mathrm{mM} \mathrm{KH}_{2} \mathrm{PO}_{4}$ and $6.3 \mathrm{mM}$

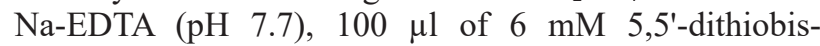
2-nitrobenzoic acid (DTNB), and $40 \mu 1$ of $5 \mathrm{mM} \mathrm{NADPH}$ in a cuvette. After blank reading, $5 \mu$ l of GR ( 1.81 units $\mu 1^{-1}$, Sigma-Aldrich) was added to activate the reaction, and increase rate of the absorbance at $412 \mathrm{~nm}$ was monitored with the spectrophotometer. To determine oxidized glutathione (GSSG) concentration, the supernatant was pretreated with 2-vinylpyridine and incubated at $25^{\circ} \mathrm{C}$ for $1 \mathrm{~h}$ to eliminate reduced glutathione (GSH). The incubated sample was centrifuged at $16,000 \times g$ for $5 \mathrm{~min}$ at $25^{\circ} \mathrm{C}$ and used for measurement of GSSG by following total glutathione protocol. A standard curve between increase rate of $412 \mathrm{~nm}$ and concentrations of GSH and GSSG was constructed using GSH and GSSG standard series, and used for the calculation of the amounts of total glutathione and GSSG concentration, respectively. The concentration of GSH was calculated from subtracting GSSG from total glutathione concentration. The redox state of glutathione was expressed as the ratio of GSH concentration to total glutathione concentration.

Data interpretation: We clarified soil salinity-induced change in $\mathrm{O}_{3}$ damage on $P_{\mathrm{N}}$ : mitigation, no effect, or enhancement. We defined mitigation effects as follow: there was significant $\mathrm{O}_{3}$-induced reduction in $P_{\mathrm{N}}$ at the $0 \mathrm{mM} \mathrm{NaCl}$ treatment but no significant effect of $\mathrm{O}_{3}$ on $P_{\mathrm{N}}$ in the $150 \mathrm{mM} \mathrm{NaCl}$ treatment. Then, to consider the mechanisms underlying the soil salinity-induced mitigation of $\mathrm{O}_{3}$ effect on $P_{\mathrm{N}}$ (i.e., protective mechanism), we focused on the salinity effects on $g_{\mathrm{s}}$, antioxidative enzymes, and antioxidants, especially under elevated $\mathrm{O}_{3}$ treatments.

Statistical analyses: In the present study, we have three factors, i.e., gas exposure, soil salinity, and leaf position, to perform analysis of variance (ANOVA). In the present case, however, it was impossible to distinguish between the effects of leaf positions and the effects of plant development stages. Thus, the data were subjected to split-plot $A N O V A$ to examine the effects of $\mathrm{O}_{3}$ and/or soil salinity on data for the net photosynthetic rate, stomatal conductance to $\mathrm{H}_{2} \mathrm{O}$, and radical-scavenging enzymes and nonenzymatic substances in each leaf position. The results presented are the means \pm standard deviation of three replicates and each grand mean is the average of 
nine plants. When a significant interaction between $\mathrm{O}_{3}$ and salinity was detected $(p<0.05)$, Tukey's HSD test was performed to identify significant differences between the gas and salinity treatments. Significant differences at $p<0.05$ by Tukey's HSD are shown by the differences in letters in the figures and tables. All statistical analyses were performed with the SPSS statistical package (SPSS 16.0, SPSS Inc., USA).

\section{Results}

Meteorological parameters: The daily mean, daily maximum, daily minimum, and 12-h mean air temperature were $18.5,25.6,13.1$, and $21.5^{\circ} \mathrm{C}$, respectively (Table 1 ). The daily mean, daily maximum, daily minimum, and 12-h mean relative air humidity were 78.5, 97.2, 52.1, and $67.1 \%$, respectively.
Ozone exposure: The daily mean $\mathrm{O}_{3}$ concentration in the $\mathrm{CF}, 1.0 \times \mathrm{O}_{3}$, and $1.5 \times \mathrm{O}_{3}$ treatments were $11.7,36.4$, and $52.7 \mathrm{nl} \mathrm{L}^{-1}$, respectively (Table 2). The 12-h mean $\mathrm{O}_{3}$ concentrations in the $\mathrm{CF}, 1.0 \times \mathrm{O}_{3}$, and $1.5 \times \mathrm{O}_{3}$ treatments were $13.3,41.2$, and $61.3 \mathrm{nl} \mathrm{L}^{-1}$, respectively. The AOT40 in the $\mathrm{CF}, 1.0 \times \mathrm{O}_{3}$ and $1.5 \times \mathrm{O}_{3}$ treatments was $0.0,4.8$, and $13.3 \mu \mathrm{LL}^{-1} \mathrm{~h}$, respectively.

Leaf gas-exchange rates: There were significant interactions between $\mathrm{O}_{3}$ and soil salinity for $P_{\mathrm{N}}$ in both leaves (Table 3). In both leaves, the exposure to $\mathrm{O}_{3}$ at $1.5 \times \mathrm{O}_{3}$ significantly reduced $P_{\mathrm{N}}$ in the $0 \mathrm{mM} \mathrm{NaCl}$ treatment while $P_{\mathrm{N}}$ was not significantly reduced in the $150 \mathrm{mM} \mathrm{NaCl}$ treatment (Fig. 1A,B). The exposure to $\mathrm{O}_{3}$ significantly reduced $g_{\mathrm{s}}$ in $7^{\text {th }}$ and flag leaves. Salinity had no significant impact on the $g_{\mathrm{s}}$ in the $7^{\text {th }}$ and flag leaves (Fig. $1 C, D$ ). Furthermore, in both leaves, no significant interactive effect of $\mathrm{O}_{3}$ and salinity was noticed on the $g_{\mathrm{s}}$ of BAW1059.

Table 1. Daily mean, daily max., daily min. daylight hour (12-h) air temperature and daily mean, daily max., daily min. daylight hour (12-h) relative air humidity inside the chambers during the treatment period in 2014. Each value is the mean of three chambers \pm SD. Daily max. - mean of daily 1-h maximum value; Daily min. - mean of daily 1-h minimum value; 12-h mean - 6:00-18:00 h.

\begin{tabular}{lllll}
\hline & Daily mean & Daily max. & Daily min. & 12-h mean \\
\hline Air temperature $\left[{ }^{\circ} \mathrm{C}\right]$ & $18.5 \pm 0.2$ & $25.6 \pm 0.6$ & $13.1 \pm 0.2$ & $21.5 \pm 0.5$ \\
Relative air humidity $[\%]$ & $78.5 \pm 0.8$ & $97.2 \pm 0.9$ & $52.1 \pm 0.5$ & $67.1 \pm 0.7$ \\
\hline
\end{tabular}

Table 2. Daily mean and 12-h mean $\mathrm{O}_{3}$ concentration and accumulated exposure over the threshold of $40 \mathrm{nl} \mathrm{L}^{-1}$ of $\mathrm{O}_{3}(\mathrm{AOT} 40)$ during daylight hours (solar radiation $>50 \mathrm{~W} \mathrm{~m}^{-2}$ ) during the treatment period in 2014. Each value is the mean of three chambers $\pm \mathrm{SD}$. $\mathrm{CF}$ - charcoal-filtered air; $1.0 \times \mathrm{O}_{3}-1$.0-fold the ambient $\mathrm{O}_{3}$ concentration; $1.5 \times \mathrm{O}_{3}-1.5$-fold the ambient $\mathrm{O}_{3}$ concentration; 12-h- 6:00-18:00 h.

\begin{tabular}{llrc}
\hline Treatment & \multicolumn{2}{l}{$\mathrm{O}_{3}$ concentration $\left[\mathrm{nl} \mathrm{L}^{-1}\right]$} & AOT40 $\left[\mu \mathrm{L}^{-1} \mathrm{~h}\right]$ \\
& Daily mean & 12-h mean & \\
\hline $\mathrm{CF}$ & $11.7 \pm 3.2$ & $13.3 \pm 3.7$ & $0.0 \pm 0.0$ \\
$1.0 \times \mathrm{O}_{3}$ & $36.4 \pm 0.2$ & $41.2 \pm 0.2$ & $4.8 \pm 0.0$ \\
$1.5 \times \mathrm{O}_{3}$ & $52.7 \pm 0.4$ & $61.3 \pm 0.2$ & $13.3 \pm 0.2$ \\
\hline
\end{tabular}

Table 3. The results of split-plot ANOVA of the effects of $\mathrm{O}_{3}$ and salinity on the leaf gas-exchange rates and activity of radical scavenging enzymes at vegetative and anthesis growth stage of Bangladeshi wheat cultivars BAW1059. Result of splitplot $A N O V A$ indicates $p$-values. Asterisks indicate levels of significance at $p<0.05\left(^{*}\right), p<0.01\left(^{* *}\right)$, and $p<0.001\left(^{* * *}\right)$, whereas ns $=$ not significant. APX - ascorbate peroxidase; DHAR - dehydroascorbate reductase; GR - glutathione reductase; $g_{\mathrm{s}}-$ stomatal conductance to $\mathrm{H}_{2} \mathrm{O} ;$ MDAR - monodehydroascorbate reductase; $P_{\mathrm{N}}$ - net photosynthetic rate; SOD - superoxide dismutase.

\begin{tabular}{lccclll}
\hline Parameter & $\begin{array}{l}7^{\text {th }} \text { leaf } \\
\mathrm{O}_{3}\end{array}$ & Salinity & $\mathrm{O}_{3} \times$ Salinity & $\begin{array}{l}\text { Flag leaf } \\
\mathrm{O}_{3}\end{array}$ & Salinity & $\mathrm{O}_{3} \times$ Salinity \\
\hline$P_{\mathrm{N}}$ & $0.026^{*}$ & $0.904^{\text {ns }}$ & $0.018^{*}$ & $0.006^{* *}$ & $0.098^{\text {ns }}$ & $0.006^{* *}$ \\
$g_{\mathrm{s}}$ & $0.044^{*}$ & $0.213^{\text {ns }}$ & $0.438^{\text {ns }}$ & $0.043^{*}$ & $0.920^{\text {ns }}$ & $0.139^{\text {ns }}$ \\
$\mathrm{SOD}$ & $0.075^{\text {ns }}$ & $0.017^{*}$ & $<0.001^{* * *}$ & $0.029^{*}$ & $0.977^{\text {ns }}$ & $0.779^{\text {ns }}$ \\
CAT & $0.025^{*}$ & $0.002^{* *}$ & $0.752^{\text {ns }}$ & $0.004^{* *}$ & $0.843^{\text {ns }}$ & $0.002^{* *}$ \\
APX & $<0.001^{* * *}$ & $<0.001^{* * *}$ & $0.048^{*}$ & $0.014^{*}$ & $0.002^{* *}$ & $0.005^{* *}$ \\
MDAR & $0.660^{\text {ns }}$ & $0.581^{\text {ns }}$ & $0.242^{\text {ns }}$ & $0.046^{*}$ & $0.910^{\text {ns }}$ & $0.048^{*}$ \\
DHAR & $0.025^{*}$ & $0.498^{\text {ns }}$ & $0.044^{*}$ & $0.571^{\text {ns }}$ & $0.008^{* *}$ & $0.924^{\text {ns }}$ \\
GR & $0.566^{\text {ns }}$ & $0.197^{\text {ns }}$ & $0.384^{\text {ns }}$ & $0.428^{\text {ns }}$ & $0.760^{\text {ns }}$ & $0.493^{\text {ns }}$ \\
\hline
\end{tabular}




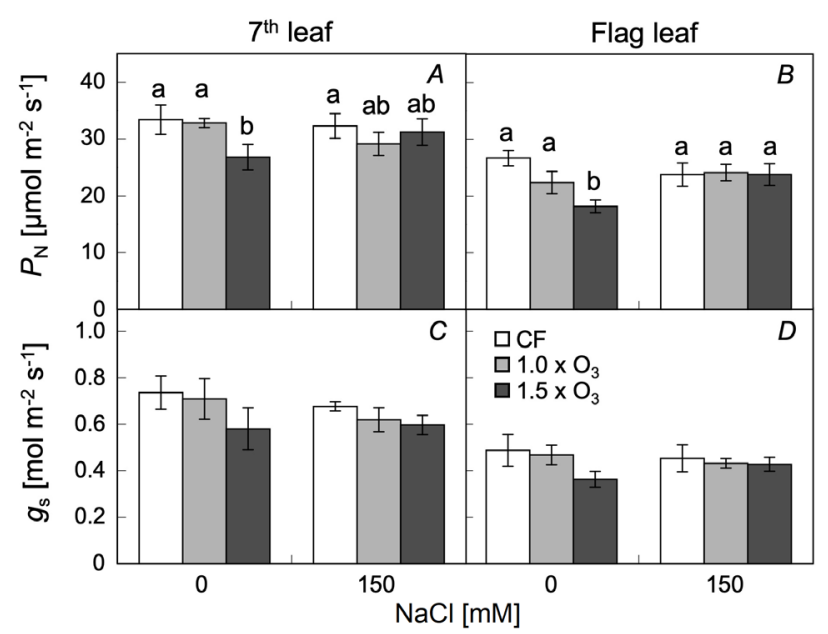

Fig. 1. Effects of $\mathrm{O}_{3}$ and soil salinity on the net photosynthetic rate $\left(P_{\mathrm{N}}\right)(A, B)$ and stomatal conductance to $\mathrm{H} 2 \mathrm{O}\left(g_{\mathrm{s}}\right)(C, D)$ in the $7^{\text {th }}(A, C)$ and flag $(B, D)$ leaves of Bangladeshi wheat cultivar BAW 1059. Values are means $\pm \mathrm{SD}, n=3$. Different letters above the bars indicate significant difference between the six treatments (Tukey's HSD test, $p<0.05$ ).

Activities of radical-scavenging enzymes: In both soil salinity treatments, the exposure to $\mathrm{O}_{3}$ significantly increased SOD activity in the flag leaf, but not in the $7^{\text {th }}$ leaf (Table 3, Fig. $2 A, B$ ). In the $7^{\text {th }}$ leaf, soil salinity significantly increased SOD activity in the CF treatment, but not in the $1.0 \times \mathrm{O}_{3}$ and $1.5 \times \mathrm{O}_{3}$ treatments. In the flag leaf, there was no significant effect of soil salinity on SOD activity.

The exposure to $\mathrm{O}_{3}$ significantly reduced CAT activity in the $7^{\text {th }}$ flag leaf in both soil treatments and in the flag leaf at the $0 \mathrm{mM} \mathrm{NaCl}$ treatment (Table 3, Fig. 2C,D). The soil salinity significantly increased CAT activity in the $7^{\text {th }}$ leaf in all the gas treatments, and in the flag leaf in the $1.5 \times \mathrm{O}_{3}$ treatment.

The exposure to $\mathrm{O}_{3}$ significantly reduced APX activity in the $7^{\text {th }}$ leaf in the both soil salinity treatments, and in the flag leaf in the $0 \mathrm{mM} \mathrm{NaCl}$ treatment (Table 3, Fig. 2E,F). The soil salinity significantly increased APX activity in the $7^{\text {th }}$ leaf in the $\mathrm{CF}$ and $1.5 \times \mathrm{O}_{3}$ treatments, and in the flag leaf in the $1.5 \times \mathrm{O}_{3}$ treatment.

In the $7^{\text {th }}$ leaf, there were no significant effects of $\mathrm{O}_{3}$ and soil salinity on the MDAR activity (Table 3, Fig. $3 A, B$ ). In the flag leaf, the MDAR activity was significantly reduced by the exposure to $\mathrm{O}_{3}$ in the $0 \mathrm{mM} \mathrm{NaCl}$ treatment, but not in the $150 \mathrm{mM} \mathrm{NaCl}$ treatment.

The exposure to $\mathrm{O}_{3}$ significantly increased DHAR activity in the $7^{\text {th }}$ leaf in the $0 \mathrm{mM}$ treatment, but not in the $150 \mathrm{mM} \mathrm{NaCl}$ treatment (Table 3, Fig. 3C,D). There was no significant effect of $\mathrm{O}_{3}$ on DHAR activity in the flag leaf. The DHAR activity was significantly increased by soil salinity treatment in the flag leaf, but not in the $7^{\text {th }}$ leaf in any gas treatment.

There were no significant effects of $\mathrm{O}_{3}$ and soil salinity and their interaction on GR activity in the $7^{\text {th }}$ and flag leaves (Table 3, Fig. 3E,F).

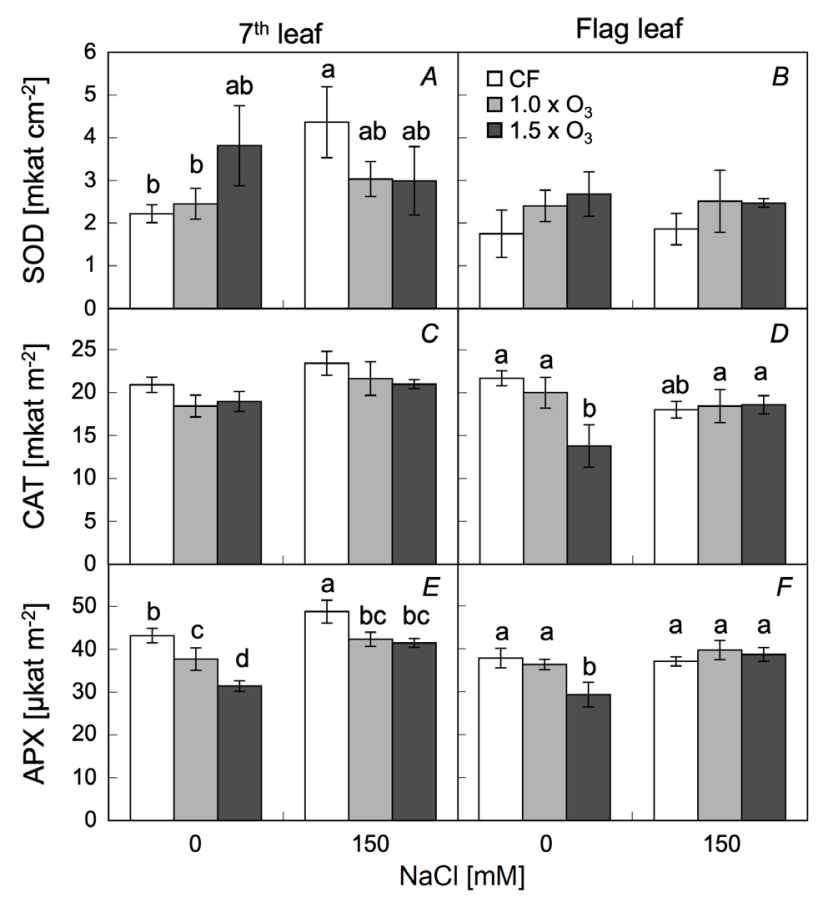

Fig. 2. Effects of $\mathrm{O}_{3}$ and soil salinity on the activities of superoxide dismutase (SOD) $(A, B)$, catalase (CAT) $(C, D)$ and ascorbate peroxidase (APX) $(E, F)$ in the $7^{\text {th }}(A, C, E)$ and flag $(B, D, F)$ leaves of Bangladeshi wheat cultivar BAW1059. Values are means \pm $\mathrm{SD}, n=3$. Different letters above the bars indicate significant difference between the six treatments (Tukey's HSD test, $p<0.05$ ).

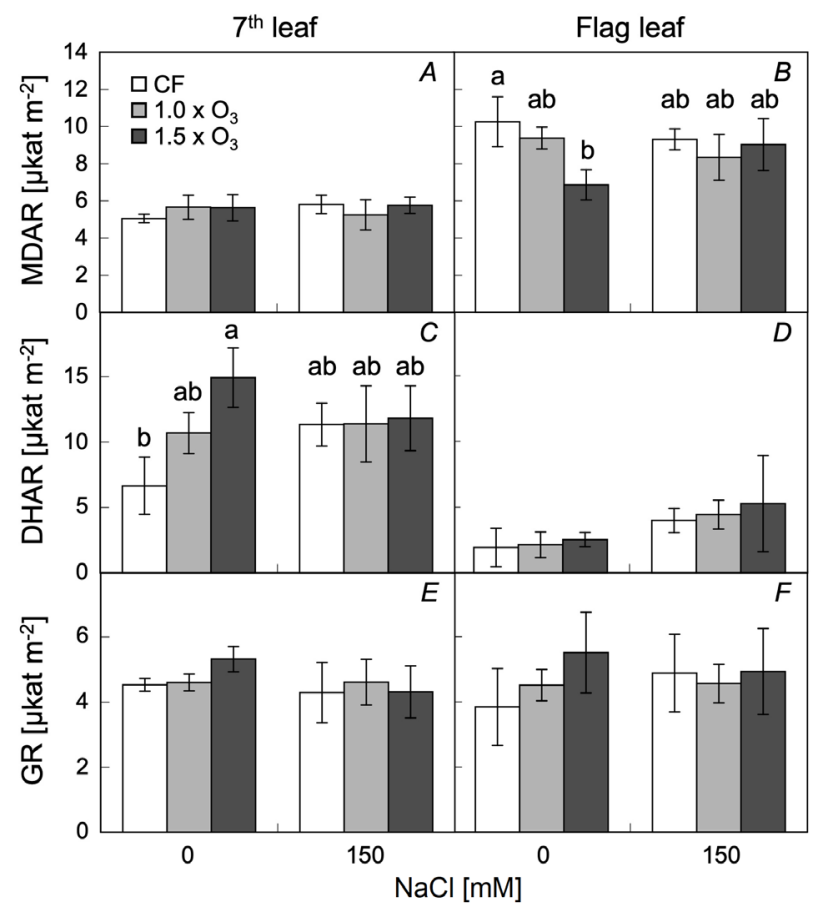

Fig. 3. Effects of $\mathrm{O}_{3}$ and soil salinity on the activities of monodehydroascorbate reductase (MDAR) $(A, B)$, dehydroascorbate reductase (DHAR) $(C, D)$, and glutathione reductase $(\mathrm{GR})(E, F)$ in the $7^{\text {th }}(A, C, E)$ and flag $(B, D, F)$ leaves of Bangladeshi wheat cultivar BAW1059. Values are means $\pm \mathrm{SD}, n=3$. Different letters above the bars indicate significant difference between the six treatments (Tukey's HSD test, $p<0.05$ ). 
Concentration and redox state of antioxidants: Exposure of $\mathrm{O}_{3}$ significantly increased the reduced ascorbate (AsA) and total ascorbate concentration in the $7^{\text {th }}$ leaf (Table 4). In the flag leaf, in contrast, concentrations of AsA and total ascorbate were significantly reduced by the exposure to $\mathrm{O}_{3}$. The soil salinity significantly increased concentrations of AsA and total ascorbate in the flag leaf, but not in the $7^{\text {th }}$ leaf. The exposure to $\mathrm{O}_{3}$ significantly reduced dehydroascorbate (DHA) concentration in the flag leaf, but not in the $7^{\text {th }}$ leaf. The DHA concentration was significantly increased by soil salinity in the flag leaf in the $1.5 \times \mathrm{O}_{3}$ treatment, but not in the $7^{\text {th }}$ leaf by any gas treatment. There were no significant effects of $\mathrm{O}_{3}$ and soil salinity and their interaction on redox state of ascorbate in the $7^{\text {th }}$ and flag leaves.

The exposure to $\mathrm{O}_{3}$ significantly increased concentration of reduced glutathione (GSH) in the $7^{\text {th }}$ leaf (Table 5). In the flag leaf, in contrast, the GSH concentration was significantly reduced by the exposure to $\mathrm{O}_{3}$. The total glutathione concentration was significantly increased by the exposure to $\mathrm{O}_{3}$ in the $7^{\text {th }}$ leaf in the $0 \mathrm{mM} \mathrm{NaCl}$ treatment, but not in the $150 \mathrm{mM} \mathrm{NaCl}$ treatment. In the flag leaf, on the contrary, the exposure to $\mathrm{O}_{3}$ significantly reduced total glutathione concentration. There was no significant effect of soil salinity on the total glutathione concentration in both leaves in any gas treatment. There were no significant effects of $\mathrm{O}_{3}$ and soil salinity and their interaction on oxidized glutathione concentration and redox state of glutathione in the $7^{\text {th }}$ and flag leaves.

\section{Discussion}

In the present study, the adverse effects of $\mathrm{O}_{3}$ on net photosynthetic rate in the $7^{\text {th }}$ and flag leaves of Bangladeshi wheat cultivar (BAW1059) were mitigated by soil salinity stress (Fig. $1 A, B$ ). In general, the degree of $\mathrm{O}_{3}$ damage is determined by the balance between stomatal $\mathrm{O}_{3}$ uptake and detoxification capacity in the leaves (Musselman et al. 2006). The stomatal $\mathrm{O}_{3}$ uptake is determined by atmospheric $\mathrm{O}_{3}$ concentration and stomatal conductance (Laisk et al. 1989). The stomatal conductance in the $7^{\text {th }}$ and flag leaves was not reduced by soil salinity stress (Fig. $1 C, D$ ). The upholding of stomatal conductance under salinity stress might be due to the fact that the cultivar with high tolerance to salinity maintains a better osmotic balance under such stress (Acosta-Motos et al. 2017). Moreover, salinity-tolerant cultivars can retain high stomatal conductance by suppressing sodium uptake (Muranaka et al. 2002). The cultivar BAW1059 was considered as salt-tolerant cultivar, due to its comparatively better protection capacity of stomatal conductance, osmotic and ionic balance, lower visual leaf injury, and delayed leaf

Table 4. Reduced ascorbate (AsA), dehydroascorbate (DHA), and total ascorbate concentrations and redox states of ascorbate in the $7^{\text {th }}$ and flag leaves of Bangladeshi wheat cultivar BAW1059, exposed to different $\mathrm{O}_{3}$ concentrations $\left(\mathrm{CF}-\right.$ charcoal-filtered air; $1.0 \times \mathrm{O}_{3}-$ 1.0-fold the ambient $\mathrm{O}_{3}$ concentration; $1.5 \times \mathrm{O}_{3}-1.5$-fold the ambient $\mathrm{O}_{3}$ concentration) and soil salinity $(0 \mathrm{mM}, 150 \mathrm{mM})$ treatments up to flag leaves stage. Each value is the mean of three chambers $\pm \mathrm{SD}$. Each grand mean is the average of nine plants. Result of split-plot ANOVA indicates $p$-value and asterisks indicate levels of significance at $p<0.05\left({ }^{*}\right), p<0.01\left(^{* *}\right)$, whereas ns $=$ not significant. Values with different letters are significantly different at $p<0.05$ between the six treatments (Tukey's HSD test).

\begin{tabular}{|c|c|c|c|c|c|}
\hline Gas & $\mathrm{NaCl}$ & AsA $\left[\mu \mathrm{mol} \mathrm{m}^{-2}\right]$ & $\mathrm{DHA}\left[\mu \mathrm{mol} \mathrm{m}{ }^{-2}\right]$ & Total $\left[\mu \mathrm{mol} \mathrm{m}{ }^{-2}\right]$ & Redox state [\%] \\
\hline \multicolumn{6}{|l|}{$7^{\text {th }}$ leaf } \\
\hline $\mathrm{CF}$ & \multirow[t]{3}{*}{$0 \mathrm{mM}$} & $974.3 \pm 87.2$ & $216.9 \pm 3.0$ & $1190.2 \pm 88.5$ & $82.9 \pm 1.0$ \\
\hline $1.0 \times \mathrm{O}_{3}$ & & $1112.5 \pm 76.4$ & $209.3 \pm 34.6$ & $1321.8 \pm 78.5$ & $84.2 \pm 2.8$ \\
\hline $1.5 \times \mathrm{O}_{3}$ & & $1237.4 \pm 41.0$ & $232.4 \pm 25.8$ & $1470.8 \pm 31.2$ & $84.1 \pm 1.8$ \\
\hline $\mathrm{CF}$ & \multirow[t]{3}{*}{$150 \mathrm{mM}$} & $1094.8 \pm 98.1$ & $243.2 \pm 24.6$ & $1337.9 \pm 116.5$ & $81.6 \pm 1.3$ \\
\hline $1.0 \times \mathrm{O}_{3}$ & & $1074.6 \pm 97.3$ & $222.5 \pm 41.1$ & $1295.1 \pm 123.0$ & $82.7 \pm 2.8$ \\
\hline $1.5 \times \mathrm{O}_{3}$ & & $1158.0 \pm 95.0$ & $236.4 \pm 37.0$ & $1394.3 \pm 132.0$ & $83.2 \pm 1.1$ \\
\hline \multirow[t]{3}{*}{ ANOVA } & $\mathrm{O}_{3}$ & $0.020^{*}$ & $0.408^{\mathrm{ns}}$ & $0.023^{*}$ & $0.439^{\text {ns }}$ \\
\hline & Salinity & $0.986^{\mathrm{ns}}$ & $0.235^{\mathrm{ns}}$ & $0.727^{\text {ns }}$ & $0.195^{\mathrm{ns}}$ \\
\hline & $\mathrm{O}_{3} \times$ Salinity & $0.141^{\mathrm{ns}}$ & $0.711^{\mathrm{ns}}$ & $0.129^{\text {ns }}$ & $0.970^{\text {ns }}$ \\
\hline \multicolumn{6}{|c|}{ Flag leaf } \\
\hline $\mathrm{CF}$ & \multirow[t]{3}{*}{$0 \mathrm{mM}$} & $631.7 \pm 57.0$ & $89.9 \pm 12.1^{\mathrm{a}}$ & $720.6 \pm 54.9$ & $86.2 \pm 1.5$ \\
\hline $1.0 \times \mathrm{O}_{3}$ & & $496.2 \pm 12.1$ & $71.4 \pm 3.6^{\mathrm{abc}}$ & $568.6 \pm 8.5$ & $86.4 \pm 0.2$ \\
\hline $1.5 \times \mathrm{O}_{3}$ & & $480.7 \pm 50.5$ & $56.1 \pm 8.5^{\mathrm{c}}$ & $536.8 \pm 59.0$ & $88.9 \pm 0.7$ \\
\hline $\mathrm{CF}$ & \multirow[t]{3}{*}{$150 \mathrm{mM}$} & $772.4 \pm 86.4$ & $80.4 \pm 7.2^{\mathrm{a}}$ & $853.7 \pm 86.0$ & $89.9 \pm 2.5$ \\
\hline $1.0 \times \mathrm{O}_{3}$ & & $580.3 \pm 86.4$ & $60.8 \pm 7.4^{\mathrm{bc}}$ & $640.1 \pm 92.9$ & $89.7 \pm 0.9$ \\
\hline $1.5 \times \mathrm{O}_{3}$ & & $628.7 \pm 204.6$ & $76.3 \pm 5.0^{\mathrm{ab}}$ & $704.0 \pm 202.6$ & $87.8 \pm 4.2$ \\
\hline \multirow[t]{3}{*}{ ANOVA } & $\mathrm{O}_{3}$ & $0.042^{*}$ & $0.002^{* *}$ & $0.023^{*}$ & $0.971^{\mathrm{ns}}$ \\
\hline & Salinity & $0.031^{*}$ & $0.999^{\text {ns }}$ & $0.030^{*}$ & $0.109^{\text {ns }}$ \\
\hline & $\mathrm{O}_{3} \times$ Salinity & $0.847^{\text {ns }}$ & $0.007^{* *}$ & $0.731^{\mathrm{ns}}$ & $0.196^{\mathrm{ns}}$ \\
\hline
\end{tabular}


Table 5. Reduced glutathione (GSH), oxidized glutathione (GSSG), and total glutathione concentrations and redox states of glutathione in the $7^{\text {th }}$ and flag leaves of Bangladeshi wheat cultivar BAW1059, exposed to different $\mathrm{O}_{3}$ concentrations $(\mathrm{CF}$ - charcoal-filtered air; $1.0 \times \mathrm{O}_{3}-1.0$-fold the ambient $\mathrm{O}_{3}$ concentration; $1.5 \times \mathrm{O}_{3}-1.5$-fold the ambient $\mathrm{O}_{3}$ concentration $)$ and soil salinity $(0 \mathrm{mM}, 150 \mathrm{mM})$ treatments up to flag leaves stage. Each value is the mean of three chambers \pm SD. Each grand mean is the average of nine plants. Result of split-plot ANOVA indicates $p$-value and asterisks indicate levels of significance at $p<0.05\left(^{*}\right), p<0.01\left(^{* *}\right)$, whereas ns $=$ not significant. Values with different letters are significantly different at $p<0.05$ between the six treatments (Tukey's HSD test).

\begin{tabular}{|c|c|c|c|c|c|}
\hline Gas & $\mathrm{NaCl}$ & $\mathrm{GSH}\left[\mu \mathrm{mol} \mathrm{m}{ }^{-2}\right]$ & $\mathrm{GSSG}\left[\mu \mathrm{mol} \mathrm{m}{ }^{-2}\right]$ & Total $\left[\mu \mathrm{mol} \mathrm{m}{ }^{-2}\right]$ & Redox state [\%] \\
\hline \multicolumn{6}{|l|}{$7^{\text {th }}$ leaf } \\
\hline $\mathrm{CF}$ & \multirow[t]{3}{*}{$0 \mathrm{mM}$} & $354.5 \pm 13.8$ & $104.9 \pm 0.9$ & $458.4 \pm 14.7^{b}$ & $77.3 \pm 0.5$ \\
\hline $1.0 \times \mathrm{O}_{3}$ & & $389.8 \pm 22.5$ & $134.3 \pm 13.9$ & $523.0 \pm 9.6^{\mathrm{ab}}$ & $73.6 \pm 3.8$ \\
\hline $1.5 \times \mathrm{O}_{3}$ & & $514.7 \pm 116.5$ & $125.0 \pm 21.8$ & $638.3 \pm 96.1^{\mathrm{a}}$ & $79.8 \pm 5.5$ \\
\hline $\mathrm{CF}$ & \multirow[t]{3}{*}{$150 \mathrm{mM}$} & $426.9 \pm 3.1$ & $139.3 \pm 4.5$ & $565.2 \pm 2.7^{\mathrm{ab}}$ & $73.6 \pm 3.6$ \\
\hline $1.0 \times \mathrm{O}_{3}$ & & $447.7 \pm 63.3$ & $150.0 \pm 28.7$ & $597.7 \pm 53.5^{\mathrm{a}}$ & $74.5 \pm 5.6$ \\
\hline $1.5 \times \mathrm{O}_{3}$ & & $455.8 \pm 47.3$ & $120.8 \pm 11.6$ & $575.6 \pm 57.4^{\mathrm{ab}}$ & $78.6 \pm 1.2$ \\
\hline \multirow[t]{3}{*}{ ANOVA } & $\mathrm{O}_{3}$ & $0.026^{*}$ & $0.084^{\mathrm{ns}}$ & $0.019^{*}$ & $0.072^{\mathrm{ns}}$ \\
\hline & Salinity & $0.351^{\mathrm{ns}}$ & $0.069^{\text {ns }}$ & $0.111^{\text {ns }}$ & $0.457^{\mathrm{ns}}$ \\
\hline & $\mathrm{O}_{3} \times$ Salinity & $0.098^{\text {ns }}$ & $0.138^{\text {ns }}$ & $0.025^{*}$ & $0.546^{\text {ns }}$ \\
\hline \multicolumn{6}{|c|}{ Flag leaf } \\
\hline $\mathrm{CF}$ & \multirow[t]{3}{*}{$0 \mathrm{mM}$} & $581.9 \pm 104.8$ & $60.6 \pm 17.5$ & $640.6 \pm 120.0$ & $91.0 \pm 1.3$ \\
\hline $1.0 \times \mathrm{O}_{3}$ & & $433.3 \pm 52.8$ & $63.7 \pm 20.0$ & $496.0 \pm 32.9$ & $86.6 \pm 5.7$ \\
\hline $1.5 \times \mathrm{O}_{3}$ & & $441.0 \pm 4.9$ & $37.7 \pm 11.0$ & $478.7 \pm 15.7$ & $92.1 \pm 2.2$ \\
\hline $\mathrm{CF}$ & \multirow[t]{3}{*}{$150 \mathrm{mM}$} & $539.8 \pm 58.8$ & $46.8 \pm 10.9$ & $585.6 \pm 49.2$ & $92.1 \pm 2.5$ \\
\hline $1.0 \times \mathrm{O}_{3}$ & & $497.3 \pm 100.3$ & $36.8 \pm 13.6$ & $533.1 \pm 86.8$ & $93.1 \pm 3.7$ \\
\hline $1.5 \times \mathrm{O}_{3}$ & & $504.3 \pm 19.8$ & $43.0 \pm 1.9$ & $547.3 \pm 19.0$ & $92.6 \pm 0.8$ \\
\hline \multirow[t]{3}{*}{$A N O V A$} & $\mathrm{O}_{3}$ & $0.047^{*}$ & $0.312^{\mathrm{ns}}$ & $0.032^{*}$ & $0.371^{\text {ns }}$ \\
\hline & Salinity & $0.361^{\mathrm{ns}}$ & $0.118^{\text {ns }}$ & $0.574^{\mathrm{ns}}$ & $0.084^{\mathrm{ns}}$ \\
\hline & $\mathrm{O}_{3} \times$ Salinity & $0.287^{\mathrm{ns}}$ & $0.176^{\text {ns }}$ & $0.252^{\mathrm{ns}}$ & $0.213^{\text {ns }}$ \\
\hline
\end{tabular}

senescence under salinity stress (Barma et al. 2011, Hasan et al. 2015, Kamal et al. 2015). That is why the stomatal conductance was not affected by soil salinity in the present study. In any case, this result indirectly suggests that the mitigation of $\mathrm{O}_{3}$ damage under soil salinity stress was not caused by reduction in stomatal $\mathrm{O}_{3}$ uptake, but by changes in nonstomatal factors, such as increase in detoxification capacity by soil salinity.

In the leaves, reactive oxygen species (ROS) are metabolized and detoxified through the radical-scavenging system to cope with oxidative stress such as $\mathrm{O}_{3}$ (Ashmore 2005, Gill and Tuteja 2010, Liu et al. 2015). SOD acts as the first line of defense against ROS by dissimulating superoxide $\left(\mathrm{O}_{2}^{-}\right)$to $\mathrm{H}_{2} \mathrm{O}_{2}$. CAT and APX convert $\mathrm{H}_{2} \mathrm{O}_{2}$ into $\mathrm{O}_{2}$ and $\mathrm{H}_{2} \mathrm{O}$, while APX uses reduced ascorbate (AsA) as an electron donor (Asada 2006). In the $7^{\text {th }}$ leaf, the soil salinity significantly increased SOD activity in the CF treatment, APX activity in the $\mathrm{CF}$ and $1.5 \times \mathrm{O}_{3}$ treatments and CAT activity in all the gas treatments (Fig. 2A,C,E). In the flag leaf, on the other hand, the activities of APX and CAT were increased by the soil salinity in the $1.5 \times \mathrm{O}_{3}$ treatments (Fig. 2D,F). These results suggest that enzymes activated by soil salinity mitigated adverse $\mathrm{O}_{3}$ effect on net photosynthesis under relatively high salt concentration in both leaves.

The activity of enzymes catalyzing regeneration of antioxidants is one of the important factors to eliminate ROS (Asada 2006, Gill and Tuteja 2010, Mishra et al. 2013). The AsA is oxidized to MDHA, which is reduced back to AsA by the activity of MDAR or disproportionate to DHA and AsA. The DHA is reduced by the reaction with reduced glutathione (GSH) catalyzed by DHAR forming oxidized glutathione (GSSG). The GSH in turn is regenerated from GSSG by GR (Asada 2006). In the $7^{\text {th }}$ leaf, there were no significant effects of soil salinity on the activities of MDAR, DHAR, and GR (Fig. $3 A, C, E$ ), suggesting that the soil salinity stress did not mitigate $\mathrm{O}_{3}$ damage via acceleration of reduction rate of antioxidants. In the flag leaf, on the other hand, DHAR activity was stimulated by soil salinity stress in all the gas treatments. Thus, in the flag leaf, soil salinity-induced higher regeneration rate of DHA might result in the mitigation of adverse $\mathrm{O}_{3}$ effect on net photosynthesis by the soil salinity stress.

In addition to the activity of enzymes catalyzing elimination of ROS and regeneration of antioxidants, the concentration of antioxidants is important for antioxidant system (Asada 2006). In the $7^{\text {th }}$ leaf, the soil salinity did not significantly affect the concentrations of ascorbate and glutathione in any gas treatments (Tables 4, 5). In the flag leaf, on the other hand, the soil salinity significantly increased the concentrations of reduced and total ascorbate, but did not significantly affect glutathione concentration 
(Tables 4, 5). These results suggest that the soil salinityinduced increases in the concentration of ascorbate and its reduction rate were related to the mitigation of $\mathrm{O}_{3}$ damage under relatively high soil salinity level in the flag leaf. We found soil salinity induced a higher tolerance to absorbed $\mathrm{O}_{3}$ via stomata in both the $7^{\text {th }}$ and flag leaves, while the mechanisms were different. Previous studies reported the response of $\mathrm{O}_{2}{ }^{-}$and $\mathrm{H}_{2} \mathrm{O}_{2}$-elimination capacity to soil salinity was changed due to the duration of salinity stress (Parida and Das 2005, Miller et al. 2010). Similarly, in the present study, the leaf-dependent difference in the mechanism of salinity-induced higher tolerance to $\mathrm{O}_{3}$ of net photosynthesis of the wheat cultivar may be due to the difference in leaf age and/or the duration of treatments.

According to Kamal et al. (2015), the yield of BAW1059 is relatively sensitive to $\mathrm{O}_{3}$ as compared to the American and European wheat cultivars. Furthermore, in a meta-analysis by Feng et al. (2008), elevated $\mathrm{O}_{3}$ (the daily mean concentration of $73 \mathrm{ppb}$ ) significantly decreased net photosynthetic rate by $c a$. $20 \%$ as compared with control (i.e., CF) treatment in wheat. In the present study, $\mathrm{O}_{3}$-induced reductions in $P_{\mathrm{N}}$ in the $7^{\text {th }}$ and flag leaves were approximately 20 and $32 \%$, respectively, by the exposure to $1.5 \times \mathrm{O}_{3}$ (i.e., $61 \mathrm{ppb}$ of $\mathrm{O}_{3}$ ) in the $0 \mathrm{mM}$ $\mathrm{NaCl}$ treatment (Fig. 1 $A, B$ ). These results suggest that BAW1059 would be sensitive or moderately sensitive to $\mathrm{O}_{3}$. On the other hand, Sikder et al. (2010) reported that the monthly daytime averaged $\mathrm{O}_{3}$ concentration in Bangladesh sometimes exceeded $60 \mathrm{ppb}(\mathrm{ca} .120 \mathrm{ppb}$ at a maximum). Such $\mathrm{O}_{3}$ concentration could adversely affect the physiology of wheat, which was clearly demonstrated in our present study at low soil salinity level (Table 2, Fig. $1 A, B)$. To prevent the adverse effects of $\mathrm{O}_{3}$ on Bangladesh wheat, exogenous application of agrochemicals, such as ethylenediurea, might be useful (e.g., Agathokleous 2017, Ghosh et al. 2018).

In conclusion, the soil salinity mitigated adverse effects of $\mathrm{O}_{3}$ on net photosynthesis in the $7^{\text {th }}$ and flag leaves of Bangladeshi wheat cultivar (BAW1059), although soil salinity did not induce stomatal closure. The mitigation of the effects of $\mathrm{O}_{3}$ was due to the change in nonstomatal factors, such as an increase in the detoxification capacity of $\mathrm{O}_{3}$ in the leaves by soil salinity. Therefore, Bangladeshi wheat cultivar with high salt tolerance, BAW1059, is expected to maintain net photosynthesis high to some extent under high levels of soil salinity and atmospheric $\mathrm{O}_{3}$.

\section{References}

Acosta-Motos J., Ortuño M., Bernal-Vicente A. et al.: Plant responses to salt stress: adaptive mechanisms. - Agronomy 7: 18, 2017.

Aebi H.E.: Catalase. - In: Bergmeyer H.U. (ed.): Methods of Enzymatic Analysis. Pp. 273-286. Verlag Chemie, Weinhem 1983.

Agathokleous E.: Perspectives for elucidating the ethylenediurea (EDU) mode of action for protection against $\mathrm{O}_{3}$ phytotoxicity. - Ecotox. Environ. Safe. 142: 530-537, 2017.

Ainsworth E.A., Yendrek C.R., Sitch S. et al.: The effects of tropospheric ozone on net primary productivity and implications for climate change. - Annu. Rev. Plant Biol. 63: 637-
$661,2012$.

Akhtar N., Yamaguchi M., Inada H. et al.: Effects of ozone on growth yield and leaf gas exchange rates of two Bangladeshi cultivars of wheat (Triticum aestivum L.). - Environ. Pollut. 158: 1763-1767, 2010.

Asada K.: Production and scavenging of reactive oxygen species in chloroplasts and their functions. - Plant Physiol. 141: 391-396, 2006.

Ashmore M.R.: Assessing the future global impacts of ozone on vegetation. - Plant Cell Environ. 28: 949-964, 2005.

Ashraf M.A., Ashraf M., Shahbaz M.: Growth stage-based modulation in antioxidant defense system and proline accumulation in two hexaploid wheat (Triticum aestivum L.) cultivars differing in salinity tolerance. - Flora 207: 388-397, 2012.

Avnery S., Mauzerall D.L., Fiore A.M.: Increasing global agricultural production by reducing ozone damages via methane emission controls and ozone resistant cultivar selection. - Glob. Change Biol. 19: 1285-1299, 2013.

Barma N.C.D., Malakar P.K., Pandit D.: Wheat Production and Seed Storage Training Manual. Pp. 1-24. Wheat Research Centre, Bangladesh Agricultural Research Institute, Dinajpur 2011.

Bellini E., De Tullio M.C.: Ascorbic acid and ozone: Novel perspectives to explain an elusive relationship. - Plants 8: $122,2019$.

Bilkis A., Islam M.R., Hafiz M.H.R., Hasan M.A.: Effect of $\mathrm{NaCl}$ induced salinity on some physiological and agronomic traits of wheat. - Pak. J. Bot. 48: 455-460, 2016.

Bortolin R.C., Caregnato F.F., Divan Jr. A.M. et al.: Effect of chronic elevated ozone concentration on the redox state and fruit yield of red pepper plant Capsicum baccatum. - Ecotox. Environ. Safe. 100: 114-121, 2014.

Feng Z.Z., Kobayashi K., Ainsworth E.A.: Impact of elevated $\mathrm{O}_{3}$ concentration on growth, physiology and yield of wheat (Triticum aestivum L): A meta-analysis. - Glob. Change Biol. 17: 580-591, 2008.

Foyer C.H., Halliwell B.: The presence of glutathione and glutathione reductase in chloroplasts: A proposed role in ascorbic acid metabolism. - Planta 133: 21-25, 1976.

Gerosa G., Marzuoli R., Finco A. et al:: Contrasting effects of water salinity and ozone concentration on two cultivars of durum wheat (Triticum durum Desf.) in Mediterranean conditions. - Environ. Pollut. 193: 13-21, 2014.

Gill S.S., Tuteja N.: Reactive oxygen species and antioxidant machinery in abiotic stress tolerance in crop plants. - Plant Physiol. Bioch. 48: 909-930, 2010.

Gillespie K.M., Xu F., Richter K.T. et al:: Greater antioxidant and respiratory metabolism in field-grown soybean exposed to elevated $\mathrm{O}_{3}$ under both ambient and elevated $\mathrm{CO}_{2}$. - Plant Cell Environ. 35: 169-184, 2012.

Ghosh N., Adak M.K., Ghosh P.D. et al.: Differential responses of two rice varieties to salt stress. - Plant Biotechnol. Rep. 5: 89-103, 2011.

Ghosh A., Singh A.A., Agrawal M., Agrawal S.B.: Ozone toxicity and remediation in crop plants. - Sustain. Agr. Rev. 27: 129$169,2018$.

Griffith O.W.: Determination of glutathione and glutathione disulfide using glutathione reductase and 2-vinylpyridine. Anal. Biochem. 106: 207-212, 1980.

Haque S.A.: Salinity problems and crop production in coastal regions of Bangladesh. - Pak. J. Bot. 38: 1359-1365, 2006.

Hasan A., Hafiz H.R., Siddiqui N. et al.: Evaluation of wheat genotypes for salt tolerance based on some physiological traits. - J. Crop Sci. Biotechnol. 18: 333-340, 2015.

Hasanuzzaman M., Hossain M.A., Fujita M.: Selenium-induced 
up-regulation of the antioxidant defense and methylglyoxal detoxification system and reduced salinity-induced damage in rapeseed seedlings. - Biol. Trace Elem. Res. 143: 1704-1721, 2011.

Hossain M.A., Asada K.: Monodehydroascorbate reductase in spinach chloroplast and its participation in regeneration of ascorbate for scavenging of hydrogen peroxide. - Plant Cell Physiol. 25: 385-395, 1984a.

Hossain M.A., Asada K.: Purification of dehydroascorbate reductase from spinach and its characterization as a thiol enzyme. - Plant Cell Physiol. 25: 85-92, 1984b.

Kamal M.Z.U., Yamaguchi M., Azuchi F. et al.: Effects of ozone and soil salinity, singly and in combination, on growth, yield and leaf gas exchange rates of two Bangladeshi wheat cultivars. - Asian J. Atmos. Environ. 9: 141-154, 2015.

Laisk A., Kull O., Moldau H.: Ozone concentration in leaf intercellular air spaces is close to zero. - Plant Physiol. 90: 1163-1167, 1989.

Liu X., Sui L., Huang Y. et al.: Physiological and visible injury responses in different growth stages of winter wheat to ozone stress and the protection of spermidine. - Atmos. Pollut. Res. 6: 596-604, 2015.

Luwe M., Heber U.: Ozone detoxification in the apoplasm and symplasm of spinach, broad bean and beech leaves at ambient and elevated concentrations of ozone in air. - Planta 197: 448455, 1995.

McCord J.M., Fridovich I.: Superoxide dismutase. An enzymic function for erythrocuprein (hemocuprein). - J. Biol. Chem. 244: 6049-6055, 1969.

Miller G., Suzuki N., Ciftci-Yilmaz S., Mittler R.: Reactive oxygen species homeostasis and signaling during drought and salinity stress. - Plant Cell Environ. 33: 453-467, 2010.

Mishra A.K., Rai R., Agrawal S.B.: Individual and interaction effects of elevated carbon dioxide and ozone on tropical wheat (Triticum aestivum L.) cultivars with special emphasis on ROS generation and activation of antioxidant defense system. - Indian J. Biochem. Bio. 50: 139-149, 2013.

Mojid M.A., Murad K.F.I., Tabriz S.S., Wyseure G.C.L.: An advantageous level of irrigation water salinity for wheat cultivation. - J. Bangladesh Agril. Univ. 11: 141-146, 2013.

Muranaka S., Shimizu K., Kato A.: A salt-tolerant cultivar of wheat maintains photosynthetic activity by suppressing sodium uptake. - Photosynthetica 40: 505-515, 2002.

Musselman R.C., Lefohn A.S., Massman W.J., Heath R.L.: A critical review and analysis of the use of exposure- and flux-based ozone indices for predicting vegetation effects. Atmos. Environ. 40: 1869-1888, 2006.

Nakano Y., Asada K.: Hydrogen peroxide is scavenged by ascorbate-specific peroxidase in spinach chloroplasts. - Plant Cell Physiol. 22: 867-880, 1981.

Parida A.K, Das A.B.: Salt tolerance and salinity effects on plants: A review. - Ecotox. Environ. Safe. 60: 324-349, 2005.

Pell E.J., Schlagnhaufer C.D., Arteca R.N.: Ozone-induced oxidative stress: Mechanisms of action and reaction. Physiol. Plantarum 100: 264-273, 1997.

Rai R., Agrawal M.: Assessment of competitive ability of two Indian wheat cultivars under ambient $\mathrm{O}_{3}$ at different development stages. - Environ. Sci. Pollut. R. 21: 1039-1053, 2014.

Saitanis C.J., Bari S.M., Burkey K.O. et al.: Screening of Bangladeshi winter wheat (Triticum aestivum L.) cultivars for sensitivity to ozone. - Environ. Sci. Pollut. R. 21: 1356013571, 2014.

Sharma P., Jha A.B., Dubey R.S., Pessarakli M.: Reactive oxygen species, oxidative damage, and anti-oxidative defense mechanisms in plants under stressful conditions. - J. Bot. 2012: 217037, 2012.

Sikder H.A., Nasiruddin M., Suthawaree J. et al.: Observation of atmospheric pollutants in Dhaka, Bangladesh. - In: Proceedings of International Conference of Environmental Aspects of Bangladesh (ICEAB10). Pp. 132-135. Japan 2010.

Wang J., Zeng Q., Zhu J. et al.: Apoplastic antioxidant enzyme responses to chronic free-air ozone exposure in two different $\mathrm{O}_{3}$-sensitive wheat cultivars. - Plant Physiol. Bioch. 82: 183193, 2014.

Wild O., Fiore A.M., Shindell D.T. et al.: Modelling future changes in surface ozone: A parameterized approach. Atmos. Chem. Phys. 12: 2037-2054, 2012.

WHO: Air Quality Guidelines: Global Update 2005, Particulate Matter, Ozone, Nitrogen Dioxide and Sulphur Dioxide. WHO Regional Office for Europe, Copenhagen 2006.

Zheng Y.H., Li X., Li Y.G. et al.: Contrasting responses of salinity-stressed salt-tolerant and intolerant winter wheat (Triticum aestivum L.) cultivars to ozone pollution. - Plant Physiol. Bioch. 52: 169-178, 2012.

Zheng Y.H., Li X., Xia W.R. et al.: Response of gas exchange, cellular membrane integrity and antioxidant enzymes activities of salt-stressed winter wheat to ozone pollution. Photosynthetica 49: 389-396, 2011.

(C) The authors. This is an open access article distributed under the terms of the Creative Commons BY-NC-ND Licence. 